\title{
STYLISTIC ANALYSIS OF MAYA ANGELOU'S EQUALITY
}

\author{
Arina Isti’anah \\ English Letters Department, Faculty of Letters, Sanata Dharma University \\ Jl. Affandi, Sleman 55281, Indonesia \\ arina@usd.ac.id
}

Received: 24 ${ }^{\text {th }}$ August 2016/ Revised: $6^{\text {th }}$ March 2017/ Accepted: $4^{\text {th }}$ May 2017

How to Cite: Isti'anah, A. (2017). Stylistic Analysis of Maya Angelou's Equality. Lingua Cultura, 11(2). 85-89. http://dx.doi.org/10.21512/lc.v11i2.1602

\begin{abstract}
This research presented the stylistic analysis of a poem by Maya Angelou, Equality. The poem was chosen as it became Angelou's one of well-known poems. The Stylistic analysis aimed at comprehending the meanings of either literary or non-literary text by means of observing the language device used in the texts. In this article, the stylistic analysis was conducted to analyze Maya Angelou's Equality. To achieve the goal of stylistic analysis, there were some language levels to observe; they were phonological, graphological, grammatical, and semantic levels. In the phonological level, the repetition of rhyme in some stanzas, assonance, consonance, and alliteration were used to voice Angelou's dream about freedom for black people. In the graphological level, the use of prominent punctuation in stanzas 3, 6, and 9 stressed equality as the requirement for the freedom she expected. In the grammatical level, Angelou used pronoun I and you as the dominant words in the poem, revealed different class the poet experienced in the country. The use of metaphors in the poem brought the same meaning as freedom, voice, effort, and racism that black people experienced in America. This research concludes that stylistics applies to analyze literary work so that thorough appreciation to it can be achieved.
\end{abstract}

Keywords: stylistics analysis, poem, language, freedom

\section{INTRODUCTION}

Stylistics deals with language style, either of literary or non-literary texts. It is mentioned that style is also related to a personality of a person. A style reflects the thoughts of a person's mind. It describes the way person's speaking and writing (Aslam, Aslam, Mukhtar, \& Sarfaraz, 2014). By observing a language user's style, at the same time, we can find out the message of ideologies brought by the language user.

In the literary text, stylistics aims at proving how language style can construct meanings, so that appreciation of literary works is not merely based on assumption. It needs language analysis of the texts. Stylistics is also proposed as a method of textual interpretation in which primary of the place is assigned to language (Simpson, 2004). Barry also supports the previous statement that stylistics is a critical approach using the methods and findings of the science of linguistics (Barry, 1995).

Research on language style in literary texts has been widely published. One of the delicate fields is language style analysis of poems. Stylistic analysis of a poem can show how poetic style creates meanings and effects (Bradford, 2005). It is not only about the poet's style, but how the poet chooses certain patterns in a stanza, for instance, can be used as linguistic evidence to draw the meaning of a poem.
There is a research conducting the stylistic analysis of Shelley's To a Skylark by employing the analysis in lexicosyntactic, phonological, graphological, and morphological levels. From the analysis, it is concluded that Shelley possesses all the romantic traits-love of nature, beauty, and imagination. This poem is rich in sensuous imagery (Shawa, 2015).

Batool et al. (2014) conduct the stylistic analysis of Frost's The Road Not Taken. To draw the meanings of the poem, the lexico-syntactic patterns, diction, phonology, graphology, and morphology are observed. It is also concluded that Frost uses simple words and phrases to make it understandable and to clarify his intentions. To convey the meanings, it is also mentioned that Frost also employs different metaphors, symbols, and images to make the poem more effective to convey his message (Batool, et al. 2014).

A similar analysis is conducted to observe Davies's Leisure. The linguistic devices which are exercised from graphology, syntax, semantics, and phonology. It is found that Davies uses very simple language in his poem by the proofs of the rhyme scheme, alliteration, and repetition. Davies makes his poem straightforwardly logical and raises a very good point in his simple structured poem to avoid boredom in reading (Hanif, Ahmed, \& Aftab, 2015).

Another research analyzes William's The Red Wheelbarrow by observing the use of phonological, 
graphical, lexical, syntactic, and semantic feature analysis. The research finds that William uses careful word choice, attention to language, and unusual stanza breaks to turn an ordinary poem into a great one (Shaheen, Jamil, \& Jahangir, 2015).

These related studies motivate the analysis of Maya Angelou's poem. Maya Angelou is one of the famous poets. Her work is often related to her personal life as a single mother and Afro American woman. Equality is a poem related to black people's experience of living in America. As an Afro American woman, Angelou experienced racism in her life. To utter her experience, in Equality, Angelou uses wordings which are fruitful to analyze. To comprehend a poem is not only based on the readers' or listeners' assumptions. The proof of language device in the poem can help the readers or listeners comprehend the message better. Thus, higher appreciation of the poem can be attained.

\section{METHODS}

Stylistic approach is conducted in this research. It concerns about the language style either literary or nonliterary text. Stylistics does not describe the language used in the text, but to figure out the language user's purpose and the text effects. The careful analysis of every line in the poem is done through the four levels as proposed by Simpson (2004).

In the phonological level, the representation of rhyme elements, alliteration, consonance, and assonance is analyzed. The repetition of certain sounds in the lines and stanzas are concerned at the phonological level. In the graphological level, the use of certain capitalization and punctuation is figured out to draw the poet's intention why she does so. In the grammatical level, the forms of words and sentences are found. In this level, the transitivity analysis is employed to figure out how the poet draws intention on each participant in the clause. In the semantic level, the use of metaphors in the poem is observed to figure out the meanings in the poem. The use of figurative language in the poem is not only for the sake of the poetic language but also for the poet's purpose why certain ideologies are reflected by means of metaphorical expressions.

\section{RESULTS AND DISCUSSIONS}

This part displays the result of the analysis. As there are four language levels observed, the discussion is broken down into its language levels: phonological, graphological, grammatical, and semantic levels.

Phonology concerns with the sound pattern of language. One of the phonological patterns found in the poem is rhyme repetition found in the last line of every stanza. Angelou's Equality contains 9 stanzas. Most of the stanzas have 4 lines, except stanzas 3,6, and 9. There is an interesting pattern in the number of lines, too. Stanzas 3, 6 , and 9 are the same. Repetition of the lines takes place in those stanzas. The rhyme in the first stanza is ABAC. The repetition of the rhyme can be seen in line 1 and line 3 . The repetition in the stanza is marked by the sound /li/ of the adverbs dimly and boldly.

$$
\begin{array}{ll}
\text { You declare you see me dimly, } & \text { line } 1 \\
\text { though I stand before you boldly, } & \text { line } 3
\end{array}
$$

In stanza 2, the rhyme is $\mathrm{ABCB}$. The repetition of the rhyme takes place in lines 2 and 4 that is shown by the sound /eindz/. Below is the appearance of the stanza.

$$
\begin{array}{ll}
\text { as a whisper out of range, } & \text { line } 2 \\
\text { and the rhythms never change. } & \text { line } 4
\end{array}
$$

Stanzas 3, 6, and 9 have 2 lines, in which one line is repeated in the other. Thus, this line is repeated six times in the poem. Therefore, the rhyme is, AA. The rhyme of this stanza is represented through the repetition of the sound / fri/.

$$
\begin{array}{ll}
\text { Equality, and I will be free. } & \text { line } 1 \\
\text { Equality, and I will be free. } & \text { line } 2
\end{array}
$$

In stanza 4, every line has different sound ending; thus its rhyme is $\mathrm{ABCD}$. The same rhyme pattern is also found in stanza 8 . There are not any repeated sound endings.

In stanza 5, the rhyme is ABCB. The second and fourth lines have the same sound ending, /a:st/. Below are the repeated lines.

we know the shameful past, line 2

and you keep on coming last.

line 4

Stanza 7 also has the same rhyme, but different sound ending representation, /rərz/. Below are the lines.

$\begin{array}{ll}\text { take the padding from your ears, } & \text { line } 2 \\ \text { and admit you've seen my tears. } & \text { line } 4\end{array}$

Another phonological feature found in the poem is assonance. It is described as the repetition of a vowel sound within a line of poetry which creates a rhythm to the poem (Batool, Khan, Iqbal, Ali, \& Rafiq, 2014). In the first stanza, the vowel /u:/ and /i:/ are repeated in the first line as follows.

You declare you see me dimly,

In lines 2 and 4, the vowel /I/ is repeated as shown in the words which, will in line 2 and trim, in, and marking in line 4. In stanzas 3, 6, and 9 the vowel /i:/ is also repeated in the words be and free. While In the other stanzas, assonance is absent.

Equality, and I will be free.

The following vowel repetition is found in stanza 4, in which the vowel /æ/ is repeated in line 2 as shown below.

that I fly from man to man,

Consonance, another phonological feature found, is the repetition of the final consonants of stressed syllables or important words in the same lines. In the first stanza, the consonant $/ \mathrm{m} /$ is repeated on line 4 as follows.

trim in rank and marking time.

In stanza 2, 3, 5, 6, 8 and 9 , consonance is absent. It is found in stanza 4 line 2, represented in consonant $/ \mathrm{m} /$ as shown below.

that I fly from man to man,

From the findings, it can be concluded that consonance is not the prominent feature used in the poem. It appears twice in which the words trim-time and man-man are used. 
Alliteration is also found in the poem. It is the repetition of the first consonant sound in two or more words in a line (Isti'anah, 2013). In stanza 1, the alliteration is found in lines 1 and 4 , in which the consonants $/ \mathrm{j} /$ and $/ \mathrm{t} /$ are repeated.

You declare you see me dimly, trim in rank and marking time.

line 1

line 4

In stanza 2, there is only one line containing alliteration, found in line 3 .

\section{while my drums beat out the message}

In the stanzas 3,6 , and 9 , there is not any alliteration found. In stanza 4 , there are two lines containing alliteration, found in lines 1 and 2, as shown below. While in the rest stanzas, alliteration is absent.

You announce my ways are wanton, that I fly from man to man,

Observing the phonological features found in Angelou's Equality, it can be seen that the repeated rhyme, vowels, and consonants bring the same message directed to the readers or listeners. The use of repeated rhyme in some stanzas attempts to attract the listeners' attention on the poet's voice. The words dimly and boldly repeated in stanza 1 shows the poet's bravery to face people's opinion towards her class as a black woman in America. It is also shown in the second stanza from the sound endings in words range and change. The poet attempts at voicing a change towards the effects of grouping social class she has experienced. The following proof, the line repetition in stanzas 3, 6, and 9 is the word free which is repeated six times in the poem. It clearly reveals freedom as the one the poet struggles to achieve. The other repeated rhyme is in stanza 7, found in words ears and tears. Here, the poet also vocalizes her pain but never paid attention to by others.

In the graphological level, Angelou uses the capital letter at the beginning of the stanzas. In stanza 1, a comma is used in lines 2 and 3. A full stop is found at the end of the stanza. In stanza 2, a quite different way of punctuating the line is found. A comma is found in line 2 only, while a full stop is put at the end of the stanza. Stanzas 3, 6, and 9 have the same pattern as the line is repeated. The beginning of the line is capitalized, and a full stop is found at the end of every line. Stanza 4 begins with a capital letter, followed using the comma in lines 1,2, and 3, and ends with a question mark as the fourth line is in the form of the question. In stanzas 5 and 7 , the same way of representing the stanzas is the same. The capital letter is used at the beginning of the stanza, followed using the comma in lines 1,2 , and 3 . There is a full stop at the end of the stanzas. In stanza 8, the capital letter is used at the beginning of lines 1 and 3, followed by a comma at the end of the line. There is a full stop in lines 2 and 4 .

The prominent use of writing the stanzas is clearly found in stanzas 3,6 , and 9 as seen below.

Equality, and I will be free.

Equality, and I will be free.

Each line is repeated and given a full stop. Here, Angelou emphasizes that there is nothing else to fulfill, but equality between the whites and blacks. The only question mark is found at the end of stanza 4, could you ever understand? The employment of such punctuation means that there is nothing asked by the government, but their recognition of the existence of black people.

In the grammatical level, the choices of words in the poem are divided into common noun, pronoun, preposition, verb, adverb, and adjective. Every word which is repeated is counted as a different word. Table 1 displays the number of types of words in the poem.

Table 1 Lexical Category in the Poem

\begin{tabular}{lcc}
\hline \multicolumn{1}{c}{ Word Category } & Number & Percentage (\%) \\
\hline Common Noun & 30 & 21 \\
Pronoun & 33 & 24 \\
Verb & 30 & 21 \\
Adjective & 12 & 8 \\
Adverb & 9 & 6 \\
Preposition & 8 & 5 \\
Conjunction & 22 & 15 \\
\hline \multicolumn{1}{c}{ Total } & 144 & 100 \\
\hline
\end{tabular}

In Table 1, pronoun dominates the word category in the poem. It appears 33 times or in $24 \%$, followed by common noun and verb, which existence appears in $21 \%$. The use of adjective, adverb, preposition, and conjunction is the minority in the poem. Adjective is used to modify a noun, such as in trim in rank and marking time. The use of preposition is to complete a verb, such as in but I keep on marching forward. The conjunction in the poem is to relate lines, such as in and you keep on coming last.

The prominent existence of word category in the poem is the pronoun. In the poem, the pronouns used are you, own, your, me, I, my, and we. Table 2 summarizes the existence of each pronoun.

Table 2 The Use of Pronoun

\begin{tabular}{ccc}
\hline Word Category & Number & Percentage (\%) \\
\hline You & 10 & 30 \\
Own & 1 & 3 \\
Your & 2 & 6 \\
Me & 3 & 9 \\
I & 10 & 30 \\
My & 5 & 16 \\
We & 2 & 6 \\
\hline Total & 33 & 100 \\
\hline
\end{tabular}

The summary use of the pronoun in the poem in Table 2 is interesting. The pronoun you and I appear in the same number, 10 times, or $30 \%$ for each. In this finding, it can be concluded that Angelou stresses the equality between you and I. The poet even pays attention to the number of word choice in the poem. The use of I as the subject reveals that black people, represented by the poet, are able to accomplish a verb as the character of the active sentence.

The common noun in the poem is used by the poet to portray the presence of black people with their conditions in the country, such as in words glass, rank, time, range, drums, rhythms, vision, and veins. The previous notion is, for example, shown in stanza 2 line 2, as a whisper out of range. The noun whisper there refers to black people's voice. 
As their voice is not really heard by the government, so it is portrayed as a whisper. The other noun range describes the black people's voice further. It is never reached by the white.

On the other hand, the use of verbs in the poem is used to reveal the actions by the pronoun. As the dominating pronoun is $I$ and you, the verbs there are related to the way the black and white people live in the country. For examples are in words know, lived, announce, hear, and beat. To comprehend the role of verbs in the poem, transitivity analysis is suitable to conduct. It talks about what happens in the clause and how each participant in the clause performs to bring the message. From the analysis, the use of transitivity types is summarized in Table 3.

Table 3 Transitivity Analysis in the Poem

\begin{tabular}{lcc}
\hline \multicolumn{1}{c}{ Transitivity Category } & Number & Percentage (\%) \\
\hline Material & 11 & 38 \\
Relational & 7 & 24 \\
Verbal & 6 & 21 \\
Mental & 5 & 17 \\
\hline \multicolumn{1}{r}{ Total } & 29 & 100 \\
\hline
\end{tabular}

Table 3 shows that the material process dominates the poem. In the material process, the verb refers to an action or a happening that is marked by an Agent as its participant. The material process can be found in stanza 1 line 3, for example, though I stand before you boldly. In line 3, I perform as an Agent, meaning the participant in the clause which does the action, represented by the verb stand.

The process of happening is shown in stanza 5 line 1, We have lived a painful history. The happening is shown by the verb live. In the poem, we perform as an Agent who experiences the happening that is followed by an Affected $a$ painful history. In that line, the black people have described to experience a long struggle in pain that is explained by the word history.

The material processes are also used in repetition in the poem through the words change and keep on, as in and the rhythms never change. The material verb change in the poem is done by the rhythms as the Agent which refers to the black people's voice to freedom. The employment of material process in that line means that what they utter to seek freedom is followed by concrete actions.

The verbal process, or saying, is marked by a Sayer as its participant who says and Verbiage as what is said. The existence of the verbal process in the poem is found in stanza 1, line 1 as shown in You declare you see me dimly. In the main clause, you performs as a Sayer or the participant who says that represented by the word declare. Here, you refers to the authority side in the country or to the white government that is called Verbiage. In line 1, the Verbiage is in the form of a noun clause, you see me dimly.

In the poem, the material process is used to show the actions done by black people. As an example, in stanza 1, line 3 . The verb stand is categorized as a material verb with $I$ as the Agent and equipped with a circumstance of the place before you and manner boldly. Angelou portrays the Agent as the one who supports the government, who stands before the white strongly. However, what she does is not respected, as shown in the preceding clause.

Another process in the poem is the relational process, meaning the process of being. It is found in stanza 3, 6 , and
9 as the line is repeated Equality, and I will be free. In the previous line, I performs as the Token, and free is the Value. The token is the participant who is defined, and Values is the participant which defines (Isti'anah, 2015). The repetition of the relational process in the poem reveals that Angelou highlights being free as the state that $I$ have. The existence of modal will refers to high possibility when the circumstance, equality, is fulfilled.

The poem also employs mental process, referring to the process of sensing or feeling. It is marked by Senser and Phenomenon as its participant. In the poem, mental process is used to describe what the white people feel or sense about the black people, as shown in stanza 1 line 1 you see me dimly. In that clause, you appear as a Senser, meaning the participant in the clause who senses, exercised by means of the verb see. Another participant, me, performs as a Phenomenon, meaning the participant who is sensed. The employment of mental process is also shown by the verbs understand, hear, and know. The minor number of mental process in the poem reveals that the white side does not feel much the pain that the black people experience. Instead, Angelou chooses to talk about the material things that her class does to seek their freedom.

In the semantic level, metaphors are found in the poem. The metaphor is described as a trope in which a word or phrase is applied to something which is not literally applicable to suggest resemblance (Shawa, 2015). The metaphor is used in some stanzas in the poem that is referring black people as ignored class and their voice. In stanza 1 line 2 and stanza 4 line 3, the metaphorical expressions refer to black people as the ignored group in the country.

through glass which will not shine,

But If I'm just a shadow to you,

The word glass refers to black people. However, the adjective clause which will not shine explains which glass meant by the poet. A glass should have the characteristic of shining as its material enables to do so. However, the shining potential owned by the black people is absent. The white people do not see the bright side of black people. Moreover, they are the ones who never give the advantage to the country. The word shadow emphasizes the previous explanation. It has the character of dark, which is opposite to the character of glass, to be clear. The presence of black people is ignored in the country. That is how Angelou portrays her class.

The other way to show black people's voice to utter their expectation in the country is through the use of repetition of words drums and rhythm. In stanza 2 line 3 below shows the metaphorical expression by Angelou.

while my drums beat out the message

The word drum does not literally mean a musical instrument. It refers to their hearts which beat the message, freedom. If they are alive, the message of freedom is always beaten following their heartbeat. In stanza 2 line 4, a clearer message is found.

\section{and the rhythms never change}

In the line above, it is not about the pattern of sound, but a strong pattern of their message when voicing freedom. The repetition of those metaphorical expression emphasizes the previous analysis. 


\section{CONCLUSIONS}

The stylistic analysis which pays attention to different language levels is proven to be able to help people to comprehend literary work better. In the phonological level, Angelou uses some repetition in both consonants and vowels in some stanzas, particularly in stanzas 3, 6, and 9 . In those stanzas, Angelou also employs marked punctuation compared to the other. The question mark is used once to stress the poet's message of the poem. In the grammatical level, the pronoun is used the most, followed by common noun and verbs. In the clause level, mental process dominates the poem, followed by material and verbal processes. In the semantic level, repetition of metaphorical expression is also exercised by the poet to voice the message. In summary, the previous findings reveal that Angelou attempts at voicing freedom of thinking as a black person living in the country so that she can develop herself and get the same chance as the white people have. The poem also portrays the ignorance of the government to the existence of the black people in the country.

\section{REFERENCES}

Aslam, S., Aslam, B., Mukhtar, P., \& Sarfaraz, A. (2014). Stylistic Analysis of the Poem "Bereft" by Robert Frost. European Journal of Research and Reflection in Arts and Humanities, 2(1), 1-5.

Barry, P. (1995). Beginning Theory. New York: Manchester University press.

Batool, S., Khan, A. B., Iqbal, A., Ali, K., \& Rafiq, R. M. (2014). Stylistic Analysis of Robert Frost's Poem "The Road Not Taken". Journal of ELT and Applied Linguistics, 2(4), 52-64.

Bradford, R. (2005). Stylistics: The New Critical Idiom. New York: Routledge.

Hanif, S., Ahmed, M., \& Aftab, M. (2015). A Stylistic Analysis of William Henry Davies" "Leisure". Journal of Literature, Languages and Linguistics, 7, 30-36.

Isti'anah, A. (2013). Language Features for More Understanding Literary Work. Literary Studies Conference (pp. 192-197). Yogyakarta: Universitas Sanata Dharma.

Isti'anah, A. (2015). Transitivity Analyses in Literary and non-Literary Texts: for Truth and Meaning. In English Language Studies for Truth and Meaning (pp. 63-78). Yogyakarta: Universitas Sanata Dharma.

Shaheen, Z., Jamil, A., \& Jahangir, N. (2015). Stylistic Analysis of the Poem "The Red Whel Barrow" by William Carlos William. European Journal of English Language and Literature Studies, 3(5), 3639.

Shawa, W. A. (2015). Styistic Analysis of the Poem "To A Skylark" by P.B. Shelley. Journal of Humanities and Social Science, 20(3), 124-137.

Simpson, P. (2004). Stylistics: A Resource Bookfor Students. New York: Routledge. 